\title{
The Measures of Modernity: The New Quantitative Metrics of Historical Change Over Time and Their Critical Interpretation
}

\author{
Jo Guldi
}

HCM 7: 899-939

DOI: $10.18352 / \mathrm{hcm} .589$

\begin{abstract}
What can digital methods tell us about modernity? This article reviews a series of recent traditional and quantitative attempts to define 'modernity' in the nineteenth century. Mass digitization allows scholars to track modernity through counts of words per year, the study of discourses (through topic modelling), and relative statistical expression over time (through divergence measurement). The results of this work confirm recent scholarship in social history that demonstrates the rising importance of meat, other food and water to national policy, as well as understudied debates on the history of fisheries. It also demonstrates that different parties in parliament had different relationships to futurity. A case study compares Liberal and Conservative party relationships to past and future through an overview of particular speakers' lexicons. As a survey of methods, this article's conclusion is that digital methods can demonstrate not only shifting values, but also require us to think about different relationships to chronology and periodization of individuals and ideas embedded in the past.
\end{abstract}

Keywords: British history, change over time, digital history, digital humanities, modernity 


\section{Introduction}

How do we measure a culture and its change over time? A question so basic as this one underlies the ability of text-mining algorithms to meaningfully tell us the most important stories of the last year, or the ways that the vocabulary of my personal email has changed over the last decade. The problem of accurately defining modernity has, of course, been at the core of the discipline of history for at least two centuries. It has also structured a series of interventions in the field of digital history over the last ten years, as scholars sought to 'proof' the applicability of data-driven questions to meaningful insights about historical themes. After a brief review of discussions of modernity in British social history and their intersection with the digital, the article reviews a series of digital humanities interventions in the measurement of historical change over time.

This article offers a retrospective of the interface between new methods and questions about how Britain became modern, highlighting the 'fit' between different methodological approaches and different questions. Comparing three major tools for understanding historical change - word count, dynamic topic models and divergence measures - offers the basis for a critical examination of the process of searching historical and cultural data, evidencing a new frontier for data-driven research. Each tool is shown to exhibit a particular bias, generating a perspective on the nature of modernity that is highly contingent on the way that the question was framed in the process of managing sources and algorithm. In the course of its review, promising questions for further research are highlighted, in particular, the problem of abstracting political influence from linguistic style, current events and conceptual change. For example, in the divergence measures of speaker innovation, politically radical speakers show up as highly 'irrelevant' to the course of history as measured from I890. The article highlights a role for critical theories of modernity to inform digital practice, underscoring that without a critical approach, the naive application of algorithms to historical databases highlights British conservatives as the leaders of the nineteenth century. In short, as data-driven studies of text engage the problem of change over time, the possible applications of algorithms to text deserve to be inspected and compared. Future refinements will require a critical engagement with theories of change over time. 
One opportunity for engaging critical thinking is the moment when a scholar chooses a particular approach to history. This problem of approach typically takes the form of a traditional theoretical question (for instance, 'when the world became modern') and a question of sources (for example, material changes in the landscape). In the era of text mining, a scholar may also choose a particular array of algorithms to help her synthesize available materials, for example, employing keyword search or topic modelling as an index to digitized sources. The problem of matching a theoretical question, particular sources and algorithmic approaches is one that the scholarly community may usefully sound in particular articles that review an array of related problems and possible algorithmic solutions. An article of this kind necessarily must focus solely on available methods, rather than proposing a particular historical answer to the total question of modernity, and thus the present commentary offers a 'methods review' of approaches to modernity rather than a final answer to any historical question in particular.

As the following paragraphs set out to show, reviewing how other scholars have handled the question of 'modernity' arms the scholar with epistemic categories that can be traced via data analysis - for instance, here what will be called 'subjective' and 'objective' accounts of modernity, or pragmatic versus conceptual versus material speech. Elsewhere, I have suggested how scholars might formally conceive of a scholarly process of 'critical search', where they describe iterations through the data in terms of the questions raised by different algorithmic approaches and scholarly theories. ${ }^{\mathrm{I}}$ As the following account demonstrates, carefully reviewing a variety of conceptual and algorithmic methods available for addressing a scholarly question results in a more powerful synthesis than any naive approach via a single tool or collection of tools alone.

\section{The Problem of Modernity}

From the early histories of the nation by Macaulay and the alternatives to national history proposed by Marx and Engels to modern debates over the role of empire and identity in modernization, an attempt to define modernity has defined the ideological positions of history and inspired the search for new methods. Desires to ground the longue durée march of 'civilization' in particular virtues and ideas have recently been traced back 
to the Enlightenment and the fiction, associated primarily with Hegel, of a total temporal 'break' with preceding generations, as Gavin MurrayMiller has recently argued. ${ }^{2}$ While twentieth-century thinkers dissolved the concept of 'civilization' into competing definitions of modernity (variously marked by class struggle, national sovereignty, the triumph of bureaucracy, technology, empire or a revolution in ideas about individuality) many of them still resonated with the concept of a radical break and a need to define the particular characteristics of the modern era. ${ }^{3}$

Within particular national traditions, the new accounts of modernity were complicated by questions about whose agency defined the structure of history, and to re-evaluate the nature of previous encounters. Murray-Miller has urged that the longue durée history of empire be reevaluated in terms of Europe's quest for self-definition and the inscription of a 'civilizing mission' upon colonial geographies. In this work, the quest to understand 'modernity' becomes self-referential, raising questions about how European elites, colonized subjects and other subalterns understood their own position with respect to time.

Historians thus have a number of obligations on their hands when it comes to interpreting change. Not only must historians make sense of an 'objective modernity', the longue durée arc of basic difference from the past, sometimes metaphorically condensed into the arrival of modern technology, coal consumption and working-class experience. ${ }^{4}$ There is also critically questioning how much of that arc was a product of increasing historical self-awareness, a product of a 'subjective modernity', typically in the form of an imagined homogeneity on the level of ethnicity or nation.

In many parts of history, the dual burden of defining objective and subjective modernities has required the application of critical theory to new archives for the purpose of locating narratives that will redefine how history is taught in the future. An important edited volume of 20I I, for example, focused explicitly on the 'Liberal Modernity' of British Empire, reform and the creation of modern party politics, showcasing scholars at the forefront of an encounter between theory and the archives. The volume drew together new work that located the modern in the governance of the social: the propagation of a myth of free trade, the rise and governance of a global city whose inhabitants were measured and surveyed and policed for the better flow of trade, and the creation of a vast bureaucracy to manage these ideals, especially as 
embodied by the Post Office, which was imagined as a fully transparent body of meritocratic experts reforming the world through the power of science. In 20I I, the tools of radical transformation were located in the archival space postcolonialism and of 'governmentality', Foucault's term for the study of the often unarticulated bias towards the management of individual lives by abstraction and quantification. The result was that historians ransacked the archives of Delhi and the Post Office, revealing both structures (like the Neoclassical rebuilding and racial segregation of Delhi) and events (like the Mazzini scandal over terrorism that ended the privacy of the mail) previously little recognized as waymarkers in the history of modernity. ${ }^{5}$ Yet even as The Peculiarities of Liberal Modernity first appeared, in another quarter of British history, new tools were already beginning to open up other methodological possibilities for testing theories of historical change.

In another quarter of history, the question of 'modernity' was being approached through an exercise in big data that underscored 'objective' change in the form of quantifiable words as an index of actual homogeneity and evolving consensus. In 20I0, historians Dan Cohen and Fred Gibbs famously applied word count measures in Google Books to measure the abstractions named by Walter E. Houghton's canonical work on Victorian Britain, The Victorian Frame of Mind, I830-I870 (I957). Armed with quantitative measures unavailable in Houghton's day, Cohen and Gibbs were able to demonstrate that nineteenth-century civilization was increasingly disengaged with religion, and increasingly enraptured by science, which only gained its modern meaning in these decades. The debate captured the imagination of readers of Victorian Studies and The New York Times alike, all while sidestepping the question of how 'Victorian Values' should be interpreted in the arc of the longue durée.

A debate about the data of modernity transpired over the next seven years, engaging specialists in Victorian newspapers and statisticians alike. Its conclusions have done much to refine our understanding of how 'Victorian Values' differed from those of the more pious thinkers of the Enlightenment and Age of Revolutions a generation before, and the Victorian embrace of a new relationship to money and the market, characterized by 'thrift' and symbolized by Samuel Smiles' classic guide to hard work, Self Help (I 859). ${ }^{6}$ At the same time, Gibbs and Cohen's preliminary work raised important issues about how keywords should be measured. 
In the process of statistical refinement that followed, the work of historical discernment moved into ever more mathematical realms, with ever more certain and clear results laying out the history of particular virtues among different British reading publics. ${ }^{7}$ In the dialogue that followed the initial publication of this finding, historians suggested that the newspaper corpus would benefit from statistical focus on a representative sample. A group of statisticians and historians headed by Thomas Lansdall-Welfare engineered just such a representative subcorpus of I2 million pages of nineteenth-century newspapers, representing a diversity of large cities and small towns across Britain and containing different class viewpoints. Both studies found an overall downward trend in the supposed set of 'Victorian Values', although the Lansdall-Welfare lab found the endurance of 'thrift' and 'patience' as virtues throughout the whole period and renewals of 'duty' and related feelings in times of war. Lansdall-Welfare's group concluded that the Victorian age was pre-eminently the moment of William Gladstone, colonial revolt and 'unrest' at home. ${ }^{8}$

The results of this process legitimized many of recent trends within British historical scholarship as directed by critical theory. At the same time, however, the results of these particular methods are also telling in their failures, which are examined in some detail with regards to their assumption of consensus and their neglect of dissent and radical currents within political speech. The 'Victorian Values' debate thus demonstrates the value not only of quantitative studies, but also of publication, redaction and the power of continued, scholarly conversation to refine preliminary measures about abstract categories by which we understand the modern condition: emotion, virtue and identity.

On a general level, a trend towards quantification seemed to underscore a sense of 'objective modernity', where countable details distinguished the present from the past at any particular time. For instance, British historians began to map the events that shaped modern experience in domains where bodies, heights and trade can be measured. ${ }^{9}$ As the 'Victorian Values' debate demonstrates, the quantitative search for objective measures of the past was not be applied solely to quantitative data: through the realm of text-mining, statistics has become newly relevant in arenas traditionally dominated by literary and discursive analysis. ${ }^{10}$ Much of the interpretive work in this domain attempted to critically evaluate the distance between questions of 'objective' and 
'subjective' modernity, for instance by tracking the temporality of references to actual persons against the dates of their life. ${ }^{\text {II }}$ At the same time, the performance of confidence in particular algorithms, as required by publications in scientific journals such as PNAS and Science, meant that data scientists often wrote about their discoveries with a naive language that enforced a sense of 'objective' and even 'final' conclusions about the past, typically implying the data-driven discovery the nature of the longue duree 'break' between pre-modern times and civilized ones - as opposed to the discovery and a critique of a 'discourse' and its role in shaping modern forms of subjecthood. ${ }^{12}$

Even while data-driven history appeared to drift away from nuance, the growing quantitative engagement with statistics was hardly devoid of innovation or critical thinking about discourses and change over time in the past. Rather than simplifying and naively asserting new discoveries, the scientists and scholars cleaved to a path of trying to shape their algorithms to discern discourses, identity, genre and change over time in the archive. In the articles of the 'Victorian Values' debate and others from the same period, an efflorescence of new algorithms and theories of measurement appeared, including hybrid approaches to counting n-grams, the development of new kinds of topic models, the application of divergence measures to texts, as well as a multitude of hybrids of these measurements, all of which promised to lend statistical rigour and nuance to the study of historical change in texts. ${ }^{13}$ Working with historical data, scholars validated the usefulness of statistical tools for detecting known historical turning points such as the formation of party discipline in parliament in the 1870 s or the succession of technologies during the British industrial revolution. ${ }^{14}$ The pattern of research in history parallels the expansion of a statistically-informed school of text mining in social science disciplines outside of history, where quantitative metrics have been applied to answer questions about categories traditionally regarded as the purview of purely qualitative reasoning, for example, social identity and social signalling within the world of speech, or indeed the realm of 'cultural hermeneutics' itself. ${ }^{15}$

The present article reviews three of the top tools associated with the examination of modernity through lexical change. Basic word counts, dynamic topic models and divergence measures are applied to the British nineteenth-century parliamentary debates for the purpose of offering a useful index of how modernity worked as an ideology in 
debate, for examining how the content of debates changed over time, and for defining the language of parliamentary debate that had the most power to persuade. At the same time, each of the approaches offers its own 'perspective' on the past, useful for highlighting particular trends (for example, materiality with respect to dynamic topic models, or speaker peculiarity within divergence measures) while obscuring others. What is lacking, in these abundant experiments, is a careful examination of how each tool refracts the possibilities of understanding change over time that takes into account some of the manifold discourse of modernity and how data might be used (or abused) in relation to theories about when the past changed and how.

\section{Modernity as Ideology and as Consensus}

The 'Victorian Values' debate operated on the basis of word counts, using raw change in word numbers as an index of an emerging consensus. The comparisons of different approaches that follow are based on the examination of parliamentary speech in Great Britain, I806-I9I I, one useful index of modernity. A relatively static genre of the parliamentary speech, while it varied in length and number from decade to decade, offers a reliable index for understanding the shifting concerns and self-understanding of parliament. ${ }^{16}$ Parliament's financial, political and global concerns also make the debates a reasonable platform for directing an overview of modernity concerned with the material categories of political economy, state-building and empire. Furthermore, analysis easily captures ingroup and outgroup, as speakers identified themselves with party but also with frontbench and backbench positions over time, as the work of Arthur Spirling's work has shown. ${ }^{17}$ Digital analysis of parliamentary debate offer a suitable background for any historian working on parts of Britain and its empire on a question of modernity, in which parliamentary dealings, alignments and debates inform issues of economy, politics and culture. It is therefore to a general portrait of modernity in the parliamentary speeches to which this article now turns.

In the case of parliament, speakers regularly invoked the concept of 'modernity' to advance claims about the ineluctable direction of society. Parliamentarians were both readers and writers of history who 
instrumentalized an account of the past in the making of party identity. ${ }^{18}$ In what came to be known as the 'Age of Reform', politicians advanced one particular definition of modernity, allied with Baconian concepts of observation, improvement and expertise, to advance an expanding range of state monitoring and improvement, varying from the reform of child labour to the provision of sewers. ${ }^{19}$

Simple n-grams, or counts of words and multiple-word phrases, afford one metric of how speakers' own conceptions changed over time. Bigrams containing the word 'modern' point us to an explicit, shared set of reference points for parliamentary speakers who self-identified with modernity, and tells us much about how they understood the modern: in terms of a written agenda for interpreting the past and the future, that comprised history, writers, poets and philosophers. Modernity was implied as the product of this written canon, with reference to the laws, legislation, doctrines, systems and practices that an understanding of modern authors suggested (see Figs. Ia and Ib).

Towards the end of the period, the words associated with modernity suggest a growing consensus about modernity as an identity and as
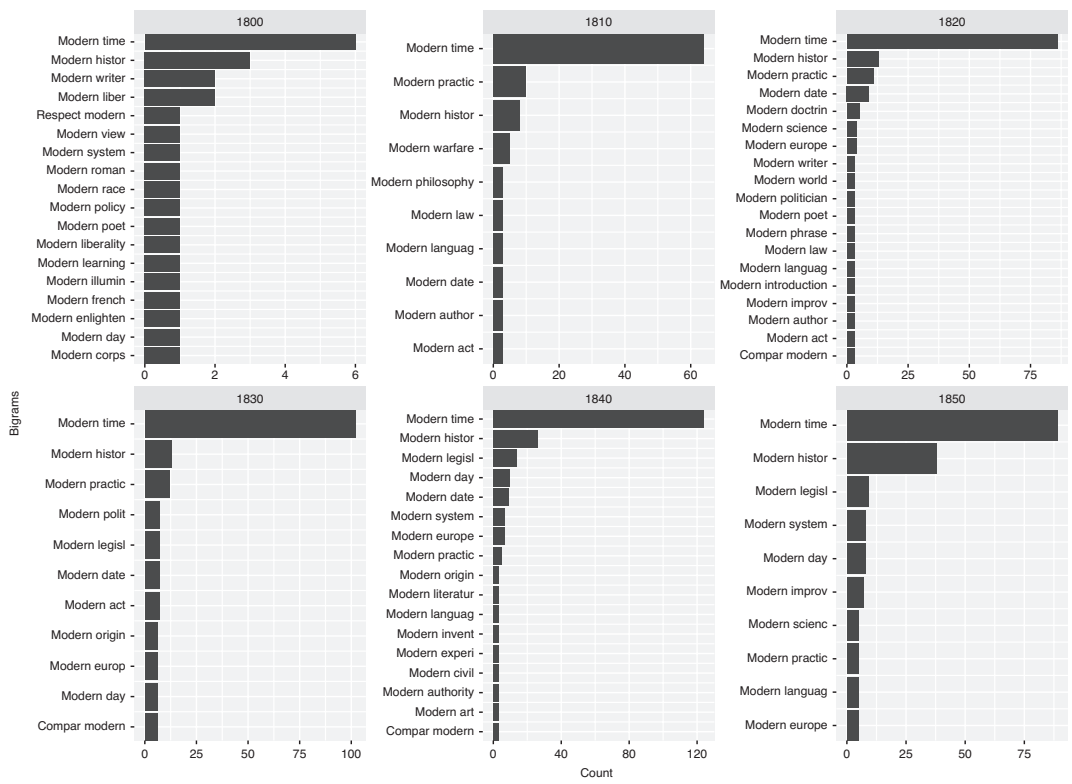

Figure Ia. Top bigrams by decade (I800-I850). 


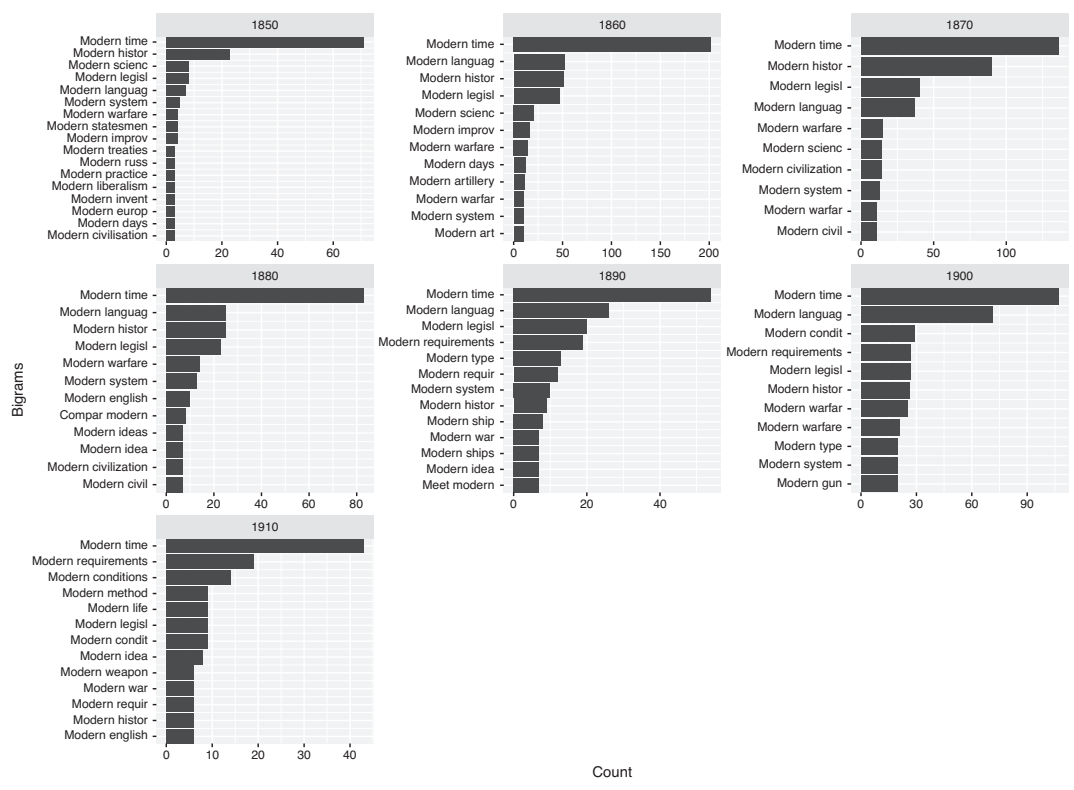

Figure Ib. Top bigrams by decade (I850-I9IO).

an inescapable certainty. Parliamentarians spoke not of 'modern poets' and 'modern law' but of 'modern life' as fact, the 'modern condition', which was distinguished in material terms by 'modern weapons' and 'modern war'. Modernity, which had started as an ideological position in the name of improvement, was now a subject of consensus: a shared identity about the (sometimes) grim necessities of politics and policy in an era of Maxim guns.

The measure of bigrams gives us an important indication of which conversations about 'modernity' were most consistently invoked as an item of self-understanding among parliamentary speakers themselves. 'Modern markets' was not a phrase routinely invoked, despite what Poovey's research suggests about the centrality of the concept to an entire body of legislation and social thought, although 'modern commerce' appeared in the list with consistency after I 850. ${ }^{20}$ More palpable is evidence of how parliamentary speakers' category of the 'modern' transformed over time: by the I 850 os modern writers yielded their place as a common reference point to modern science, improvement, and invention, as well as modern commerce (although modern historians 
and poets retained a powerful place on the list). Thus the invocation of 'modernity' by speakers who identified themselves with the future in any given decade resonates with an account of the increasingly technocratic governance of modern life by government experts.

Even in counting words, the observer's categories matter deeply. To borrow a classification from the social sciences, in dealing with any group of speech-acts from a community, a scholar must distinguish a 'participant' language, used by speakers to distinguish their own categories, from an 'observer' language applied by the observer to explain the 'what' or the 'why' of the society in question. ${ }^{21}$ The 'modern laws' and 'modern poets' of parliament may signal a 'subjective modernity' at work in how parliamentary elites saw themselves and their work.

Despite their illumination of the subjective, bigrams also have limits. They depend on the individual researcher to conjure up the entire host of interchangeable idioms that might seed a successful query, which in the case of searching for 'modernity' should expand past the 'modern' to include, at minimum, terms such as 'civilization' and 'imperial'. N-grams that trace values such as these also necessarily, like the search for 'Victorian Values', frequently return results that bear more on changes to 'subjective' modernity than 'objective' modernity.

Illuminating though this 'subjective' index of modernity may be, it makes a poor proxy for 'objective' historical change in general. It is limited, of course, as an index by tracking the record of speech-acts by white, male, privileged members of parliament. The keyword 'modernity' in the bigrams above also signals a particularly self-reflective stance on parliament's work. In many instances, allusions to 'modern civilization' backed up a paeon to empire and the burden of bringing European civilization to the rest of the world, as when Charles Adderly described the demand of Australia and India for 'postal facilities, the great instrument of modern civilization'. ${ }^{22}$ Praise of modern legislation, improvements and history often thus accompanied an attempt by a parliamentary speaker to impose a European notion of the longue durée of civilization onto the rest of the world. The bigrams thus represent a particularly pragmatic application of speech for the purpose of advancing an agenda: it represents less the universal embrace of a set of Victorian virtues, than an attempt by parliamentary speakers to universally coerce the peoples of the world into a single mould of behaviour, through a break with traditional economies and politics. 
Such an interpretation is well and good, and is aided by insights lent by modern intellectual historians and a critical eye to Victorian ideology. On the other hand, the keyword-based measure of bigrams lacks the ability to track concepts through linguistic substitutions, and as such it makes a poor tool for following the changing language used to describe any general category of knowledge. Discussions of the 'modern' - the canonical, the instructive, as embodied by routine two-word phrases - makes up a minority of what was actually debated, of course, and the actual content of the debates is liable to illuminate the world of policy with greater subtlety and precision. The limitations of keyword count are symptomatic of one particular approach to digitized sources: they capture turns of phrase that reflect idioms of speech or objects of intellectual fascination - concepts or linguistic shifts - rather than an 'objective modernity' indexed by those words. In order to underscore this point, it is necessary to compare keyword search to one of the other most popular approaches to digitized texts: the topic model.

\section{Modernity as Content}

Among many digital humanists, an emerging consensus suggests that topic models act better than keyword searches as an index to the objects of concern in a corpus of historical texts. ${ }^{23}$ Literary researchers have experimented with topic models specifically related to nouns, reasoning with Foucault that post-enlightenment forms of knowledge accreted around 'objects' of knowledge related to progress in the material world. ${ }^{24}$ Digital historians have also used topic models to link 'objects' of historical experience to political arrangements (for example, the telegraph and the state regulation of private monopoly) and changes in linguistic expression (for example, interruption in parliament, linked to the Irish Land War). ${ }^{25}$ Accordingly, a topic model provides a starting-point for an index of the material events and landscapes that marked modern British experience from the viewpoint of parliament. ${ }^{26}$

Scholars have experimented with using topic models as an index for change over time. In 2006, David Blei introduced a variation of his original topic-modelling algorithm that handled historical data about time. The result, called 'dynamic topic modelling', detected change over time in aggregate patterns of language. ${ }^{27}$ Another variation of 
dynamic topics (the Non-Negative Matrix or NMF) has been successfully applied to the study of changing debates over decade-long timespans in the European Parliament, and on the basis of this result, the present study applies NMF dynamic topics to Hansard's parliamentary debates of Great Britain, the major source for transcriptions of speeches from the House of Lords and House of Commons. ${ }^{28}$ A 500topic model of all Hansard in the nineteenth century evidences many themes familiar to readers of British history, including the transport revolution (one topic on turnpikes, another on railways). ${ }^{29}$ The multiple topics that concern these events are actually quite distinct, ranging from discussions of architects' plans for urban parks to the governance of London's infrastructure, including bridges, streets, river and telephone cables. ${ }^{30}$ Eviction has its own topic (paired with applications for railway construction, for various licenses, the regulation of lodging houses and allotment gardens). ${ }^{31}$ There are also topics that evidence a wider revolution in infrastructure and landscape than is usually described in treatises on urbanization and transport, many of them intimately related to the infrastructure of empire: the rise of shipbuilding, including the construction of yards and docks; private bills specifically for making docks; the role of rail lines and roads around empire in deploying soldiers; naval infrastructures; military and colonial properties; the infrastructure of empire after the mutiny, especially the construction of barracks for British soldiers around the world; and the spreading of county roads, gaols and asylums across England and Ireland. ${ }^{32}$

As many scholars have shown elsewhere, topic models can prove an invaluable finding aid for locating debates, places and themes in relationship with each other. To examine one topic model in particular, the topic labelled 'Supply of Water, Food, and Meat' (Table I) shows parliament debating a changing range of subjects, from oats and barley in I 800, to the shortfall of food in I8IO, the water companies in I 820 , the potato famine in I840, London's sewerage in the I850s, demands for gas and meat in the I860s, the pollution of urban water sources in the I 870 s, and from the I $880 \mathrm{os}$, a new conversation about the provision of meat and butter to troops and citizens. The topic also raises possible research questions about the discourse of want over time and implicit relationships between the idea of 'want' and artificial or natural 'supply' as handled in different generations. The topic underscores the way that a discourse about cheap grain motivated not only a conversation 
Table I: Topic I50, 'The Supply of Water, Food, and Meat', via a dynamic topic model $(k=500)$ of Hansard's parliamentary debates, I803-I9II.

\begin{tabular}{|c|c|c|c|c|c|}
\hline I800 & I8IO & 1820 & I840 & I850 & I860 \\
\hline $\begin{array}{l}\text { suppli } \\
\text { defici } \\
\text { meat } \\
\text { information } \\
\text { contractor } \\
\text { deficiency } \\
\text { provid } \\
\text { demand } \\
\text { contract } \\
\text { oat } \\
\text { seed } \\
\text { surplus } \\
\text { qualiti } \\
\text { company } \\
\text { barley } \\
\text { investigated } \\
\text { believe } \\
\text { supply } \\
\text { want } \\
\text { compromis }\end{array}$ & $\begin{array}{l}\text { suppli } \\
\text { majesty } \\
\text { regular } \\
\text { rais } \\
\text { defici } \\
\text { food } \\
\text { supply } \\
\text { water } \\
\text { furnish } \\
\text { demand } \\
\text { bills } \\
\text { voted } \\
\text { applied } \\
\text { trust } \\
\text { quarter } \\
\text { ballot } \\
\text { token } \\
\text { quantiti } \\
\text { agricultur } \\
\text { direct }\end{array}$ & $\begin{array}{l}\text { suppli } \\
\text { water } \\
\text { metropolis } \\
\text { commiss } \\
\text { engin } \\
\text { river } \\
\text { burdett } \\
\text { bath } \\
\text { analysi } \\
\text { metropoli } \\
\text { thames } \\
\text { wholesom } \\
\text { supply } \\
\text { procur } \\
\text { companies } \\
\text { calvert } \\
\text { defici } \\
\text { steam } \\
\text { inquir } \\
\text { quality }\end{array}$ & $\begin{array}{l}\text { suppli } \\
\text { food } \\
\text { want } \\
\text { potato } \\
\text { water } \\
\text { crop } \\
\text { defici } \\
\text { purchas } \\
\text { fever } \\
\text { diseas } \\
\text { seed } \\
\text { indian } \\
\text { people } \\
\text { supply } \\
\text { depend } \\
\text { obtain } \\
\text { quantiti } \\
\text { grain } \\
\text { demand } \\
\text { cheap }\end{array}$ & $\begin{array}{l}\text { suppli } \\
\text { water } \\
\text { river } \\
\text { metropoli } \\
\text { metropolis } \\
\text { supply } \\
\text { companies } \\
\text { thame } \\
\text { arm } \\
\text { thames } \\
\text { cloth } \\
\text { drainag } \\
\text { quantiti } \\
\text { mowatt } \\
\text { rifl } \\
\text { sewag } \\
\text { inhabit } \\
\text { sewer } \\
\text { defici } \\
\text { furnish }\end{array}$ & $\begin{array}{l}\text { suppli } \\
\text { supply } \\
\text { cotton } \\
\text { water } \\
\text { friday } \\
\text { cloth } \\
\text { gas } \\
\text { meat } \\
\text { store } \\
\text { demand } \\
\text { price } \\
\text { want } \\
\text { market } \\
\text { sitting } \\
\text { contractor } \\
\text { quantiti } \\
\text { nights } \\
\text { food } \\
\text { timber } \\
\text { estimates }\end{array}$ \\
\hline I870 & I880 & I890 & I890 & 1900 & I900 \\
\hline $\begin{array}{l}\text { water } \\
\text { suppli } \\
\text { supply } \\
\text { river } \\
\text { metropoli } \\
\text { constant } \\
\text { metropolis } \\
\text { pollut } \\
\text { gas } \\
\text { companies } \\
\text { metropolitan } \\
\text { lake } \\
\text { thame } \\
\text { suffici } \\
\text { feet } \\
\text { obtain } \\
\text { store } \\
\text { manchest } \\
\text { pure } \\
\text { want }\end{array}$ & $\begin{array}{l}\text { suppli } \\
\text { water } \\
\text { supply } \\
\text { food } \\
\text { firm } \\
\text { set } \\
\text { contractor } \\
\text { seed } \\
\text { store } \\
\text { manufactur } \\
\text { price } \\
\text { cloth } \\
\text { sword } \\
\text { articl } \\
\text { tender } \\
\text { messrs } \\
\text { drink } \\
\text { furnitur } \\
\text { suffici } \\
\text { ammunit }\end{array}$ & $\begin{array}{l}\text { water } \\
\text { supply } \\
\text { river } \\
\text { companies } \\
\text { consum } \\
\text { east } \\
\text { birmingham } \\
\text { boiler } \\
\text { thame } \\
\text { sanitari } \\
\text { tub } \\
\text { drink } \\
\text { area } \\
\text { boilers } \\
\text { pollut } \\
\text { reservoir } \\
\text { cut } \\
\text { quantiti } \\
\text { purposes } \\
\text { health }\end{array}$ & $\begin{array}{l}\text { suppli } \\
\text { supply } \\
\text { meat } \\
\text { troop } \\
\text { friday } \\
\text { contractor } \\
\text { forag } \\
\text { tender } \\
\text { sourc } \\
\text { firm } \\
\text { seed } \\
\text { august } \\
\text { defici } \\
\text { ammunit } \\
\text { canteen } \\
\text { station } \\
\text { qualiti } \\
\text { food } \\
\text { quantiti } \\
\text { suffici }\end{array}$ & $\begin{array}{l}\text { meat } \\
\text { supply } \\
\text { food } \\
\text { electr } \\
\text { contractor } \\
\text { firm } \\
\text { troop } \\
\text { light } \\
\text { copi } \\
\text { allot } \\
\text { store } \\
\text { tender } \\
\text { lymph } \\
\text { ration } \\
\text { beef } \\
\text { demand } \\
\text { liquor } \\
\text { tin } \\
\text { ammunit }\end{array}$ & $\begin{array}{l}\text { water } \\
\text { boiler } \\
\text { tub } \\
\text { boilers } \\
\text { supply } \\
\text { butter } \\
\text { companies } \\
\text { river } \\
\text { stock } \\
\text { outsid } \\
\text { bellevill } \\
\text { engin } \\
\text { joint } \\
\text { thame } \\
\text { arbitr } \\
\text { corpor } \\
\text { bulk } \\
\text { type } \\
\text { metropolitan } \\
\text { cylindr }\end{array}$ \\
\hline
\end{tabular}


about free trade in the I840s, but also an expanding array of conversations about the role of government in sanitizing supplies of food and water over the rest of the century. The topic model largely confirms what Chris Otter has called 'The Nutrition Transition' as one of the crucial arenas wherein the poles of debate were constructed for both an ideology of the free market and an ideology of a growing state bureaucracy. In this food-driven process, the pulse of famine and supply symbolized by changing loaf sizes as regulated of the medieval Assize of Bread was adjusted into a modern regime of plentiful, cheap food and fat bodies, designed by parliamentary expertise, and regulated at a global level. ${ }^{33}$

Topic modelling is typically useful in instances like this one, where it confirms events known to contemporary scholars. The use of the tool is in offering a bird's eye view of persistent and changing subjects of debate, in which most scholars of British history will recognize some part of their study. Other familiar topoi of modernity visible in topic form include the creation and regulation of schools, the national gallery, the importance of military pensions, the regulation of marriage, from clandestine marriage to married women's property; the management of the children of the poor in factories and workhouses; and discussions of loss and death (where the computer finds a similar language in discussions of religion, taxation and motor vehicle accidents). As for the table of contents of a textbook on modern Britain, the subjects reviewed by a topic model of Hansard give a rapid overview of the categories of historical experience debated and regulated in parliament.

The topic model's use to most scholars will be in its capacity to provide context for a particular micro-historical debate (for instance, fisheries in Aberdeen) as it underscores how the same language or ideas appeared elsewhere. As to the view of modernity, it allows the historian to synthesize a narrative about how the British landscape was changing in aggregate: not from the viewpoint of Macadam the civil engineer, but in the rapid-play overview of a hundred years, like that of Hoskins, but with all of the detail of parliamentary attention to African railways, Scottish fisheries and Indian barracks. In this way, the view from the topic model (quantitative and unbiased, approached via Hansard rather than via the archive) confirms and validates the view of an international, imperial, and governmental modernity as defined by the recent work in British social history described above. 
Topic models lend insight into raw word counts of Victorian virtues. For example, far from a set of virtues appearing as a topic of related ideas, Victorian virtues appear related to the 'Turnpike Trust' topic, where a unique set of virtues tend to collocate, signalling the values that turnpike trustees wished to be accredited with (or, in other debates about turnpike trust dissolution: were charged with not having): 'persever*', 'serious', 'acced*', 'sincer*', 'confid*', 'satisfactori*', 'secur*', 'assur*'. In this way, the context provided by a dynamic topic model offers a corrective for the possible naiveté of a rising consensus about 'Victorian Values' suggested by studies based on counting keywords.

Topic models, of course, have their own limits: they were designed to capture collections of words, not primarily to study the dynamics of change, or the coming and going of trends. Even visualizations like Figure I only suggest imprecise trends in word usage. While topic models provide insight into when collections of ideas peaked and how they changed, accurate detection of change entails closer inspection of the rise and fall of individual players and words. The world of information theory, and, in particular, measures of divergence, have lately provided scholars with a remarkable set of tools for apprehending how the role of particular speakers changed over time. Therefore, this survey of methods necessarily shifts to one of the top candidates for hybrid approaches, the measures of divergence being imported into history from information theory, which is rapidly becoming one of the chief tools for identifying correlations over time.

\section{Information Theory and the Study of Change Over Time}

Information theory has become increasingly important of late to scholars seeking to address the nature of historical change. Over time, these digital examinations of the past have showed a higher bar on the statistical definition of change over time, an attention to the categories of change rather than simple lexicon counts. Notable examples of this work are now foregrounding the measure of change over time itself.

Divergence measurement allows scholars to hone in on a 'signal' of change, comparing a variety of different topics, speakers or individual words to identify the ones most related to a changing statistical 
expression. In a now classic paper, Hitchcock and DeDeo examined lexicon change in the records of the Old Bailey, the central criminal court of England and Wales, and found that 'violence' was the semantic category of terms whose counts underwent the most significant transition over time, with descriptions of violent crime undergoing a marked decrease over the course of the eighteenth and nineteenth centuries. ${ }^{34}$ More broadly, a budding industry of keyword counting and statistical comparison has made preliminary approaches to both intellectual history and the genesis of the nineteenth-century novel..$^{35}$ In the context of parliamentary debates, divergence measures have been used to highlight the relationship between individual speakers and change..$^{36}$ In the paragraphs that follow, this article will emulate that work by focusing on individual speakers, with some meditations on the promise and limits of that method.

From information theory comes the use of a partial 'JensenShannon divergence' for comparing individual documents to the entire corpus. In contrast with a 'full' divergence measure, which is used to compare two lexica, a partial JSD measure can be used to calculate the distance between each word's probability in year $\mathrm{p}$ and its probability in year q:

$$
\text { distance }=p \times \log \left(\frac{p}{\frac{1}{2}(p+q)}\right)
$$

Applying partial JSD to search for words that are more likely to appear in Hansard in I852-I9I I as measured against I803-I85I reveals a list that shows the decline of feudal institutions ('nobl-', 'house', 'majesti-'), the evanescence of a language of consensus based on universal standards ('law', 'principl-', 'motion', 'proceed-', 'country') and the disappearance of an eighteenth-century language of allusion to the informed public ('respect-', 'learn-', 'public,' 'opinion') (see Fig. 2). The same list suggests the expansion of state institutions to serve a democratic nation ('school', 'educ-', 'board-', 'secretari-'), the contestation of local against national politics ('counti-', 'council-'), the rise of a language of democratic advocacy ('beg', 'posit-', 'claus-', 'question', 'deal', 'bill', 'regard'), and the consequent rise of contestations of the ownership of estates by different public and private authorities ('land'). 


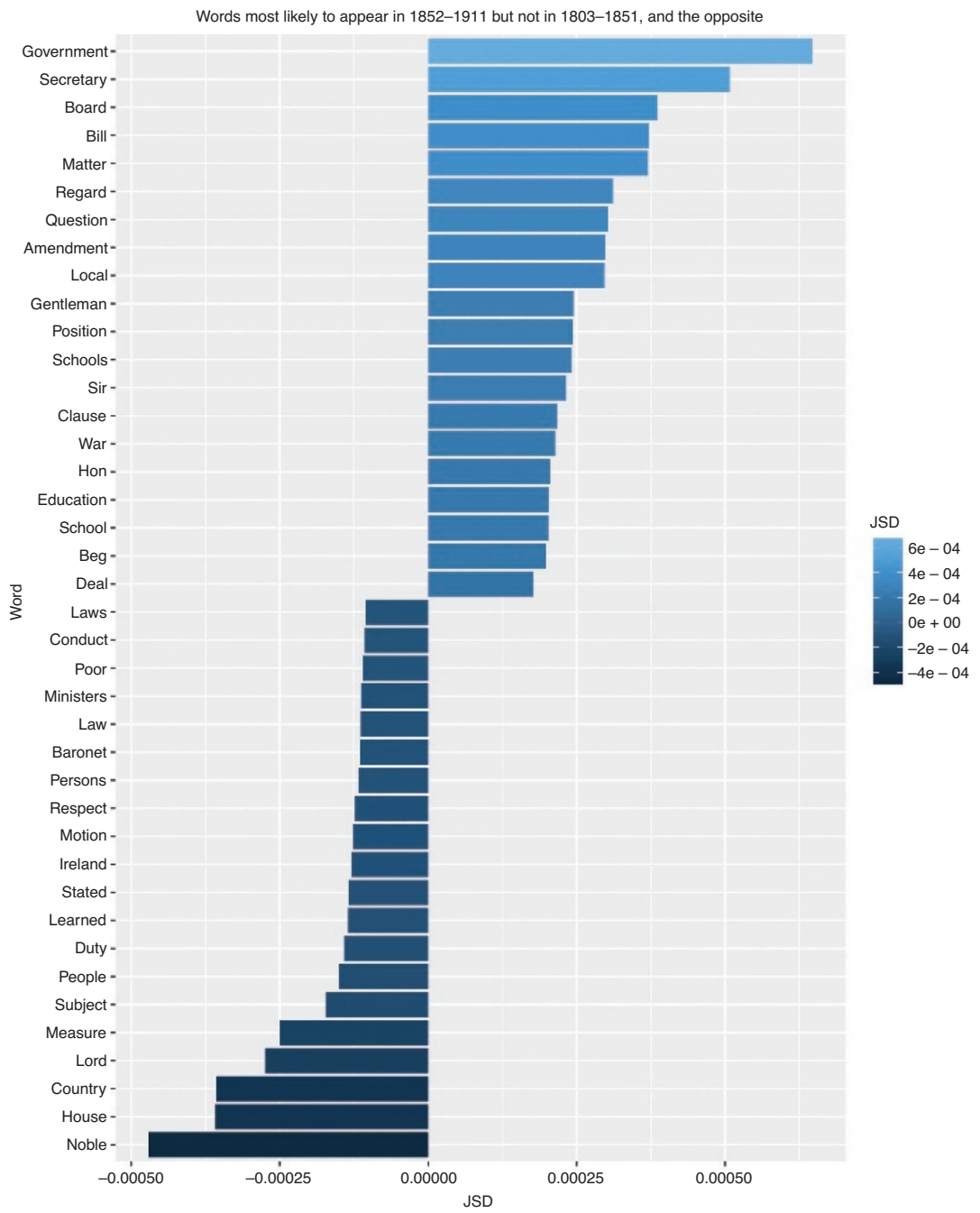

Figure 2. Words statistically more likely to occur in I852-I9I I than I803-I85I, according to a partial-JSD measurement of Hansard's parliamentary debates.

Generalizations, of course, mask trade-offs that become visible at a finer scale of reflection. Statistical categorization makes possible the sorting of parliamentary speakers into those whose speech was more 'innovative' (or more likely to resemble speech over the coming decade) and those whose speech was more 'irrelevant' (and more likely to resemble debates over the previous decade). A key text is new work 
on the French Revolution by Alexander Barron, Simon DeDeo and Rebecca Spang, which used divergence measures (or the distance of a probability series of words) to distinguish the speakers who were most 'novel', or whose words were regularly different from those widely used in the past, and speakers who were most 'transitive', or whose words were distant from the words that would be spoken in the future. ${ }^{37}$ The annals of Britain's parliament over the nineteenth century offers a longer time series of speakers and years available for parliament, and the longue durée of a century offers a different insight than the courte durée of a decade in the French Revolution. Indeed these measures allow us to compare a similar set of relationships to time: here, given the names 'innovation' and 'irrelevance' rather than 'novelty' and 'transitoriness', so as to stress the potential political virtue ('innovation') associated with distance from the past, and the potential political cost ('irrelevance') of distance from the future.

The approach taken here was chosen so as to dramatize, and make available to critique, the dynamics of information theory. It thus represents a slightly simplified version of the approach forwarded elsewhere, where divergence measures were used to take the distance between speakers as represented by a probability distribution of their use of topics. Here, divergence is used to directly measure the difference between speakers' words. For each year in which a speaker worked, the algorithm measures the distance between the speaker's lexicon in a particular calendar year and 'the past' (that is, everything that all speakers said in the preceding time horizon) and relative to 'the future' (that is, everything that all speakers said in the succeeding time horizon). Speakers are then scored for each year, and total speaker scores represent the average of their scores for each year. The benefit of this method is that it allows a scholar to rank speakers in relation to 'the future' itself, thus making available a quantitative measure of 'modernity' itself, rather than testing contemporary ideation about 'the modern' (as bigrams did) or using all apprehendable forms of collective change over time as a proxy for modernity (as the topic model did). In theory, the tool allows a scholar to distinguish individuals who consistently anticipated historical movements from individuals who consistently bucked the trends of their time, and then to specify the language that marked out innovation.

The measurement of modernity here definitely represents an innovation in historical methods. Of course, any attempt to translate 
qualitative reasoning into quantitative measures also introduces forms of bias, which are instantiated in the form of categories that are liable to debate, for instance, the cut-off dates used to distinguish 'the future', the concept of the individual and the search for patterns of change at the level of lexicon rather than topic. A section below will foreground some possible issues.

While those questions hold, modelling nevertheless produces some interesting findings. A DeDeo Plot of Hansard reveals a bulletlike structure to parliament, with a dense cluster of speakers who are equally innovative in their discussions of new issues with language that would have been atypical for speakers ten years before. A strong diagonal line is a line of equilibrium between innovation and irrelevance (what Barron et al call 'novelty' and 'transience'): in general, the more innovative a speaker was and the more they introduced new words, the more of a 'penalty' they paid in terms of their colleagues' attention. In contrast, the more a speaker adopted the lexicon of other speakers in the past, the more likely they were to have the power to influence the

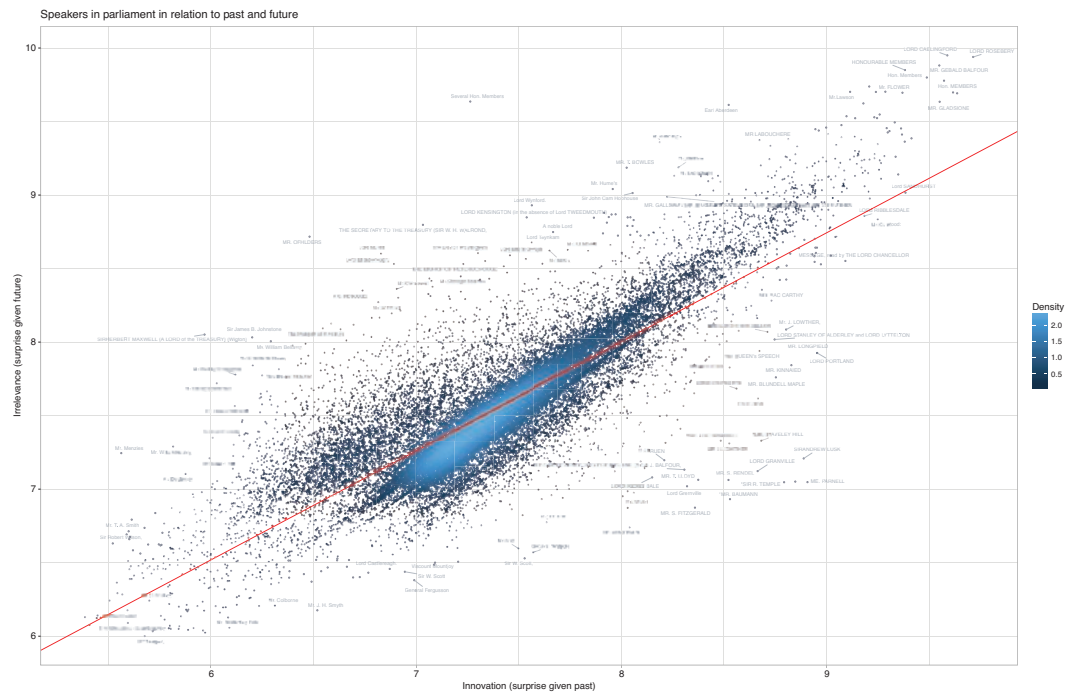

Figure 3. Relationship to past and future in speakers' lexicons in Hansard, I8IO-1900. DeDeo plot measuring innovation (distance from past) against irrelevance (distance from future), as calculated by Kumar-Johnson distance to the lexicons of speakers ten years before and after the year of each speech. 
parliamentary speech of others in the future. The diagonal indicates that parliament favoured an overall (small ' $c$ ') conservative bias towards language - the language for speaking about things used by other speakers in the past.

The major cluster of these speakers, however, were also relatively irrelevant in ten years' time, speaking a language that would be unfamiliar to their heirs in the future (see Fig. 3). Outliers can be identified, including those speakers who were relatively more irrelevant than their peers, and relatively more innovative as well as more relevant than their contemporaries.

Looking for the language that clustered around speakers who were 'innovative', that is, trending strongly towards the future, offers an index of change towards the modern, broken down not only by decade but also by speaker. The procedure classifies speakers as 'innovative' whose lexicon is closer to the language spoken in the ten years following the year of speech. Words used by 'innovative' speakers are then measured against words used by 'irrelevant' ones, and the result is an index of change that is sensitive to party and individual speakers.

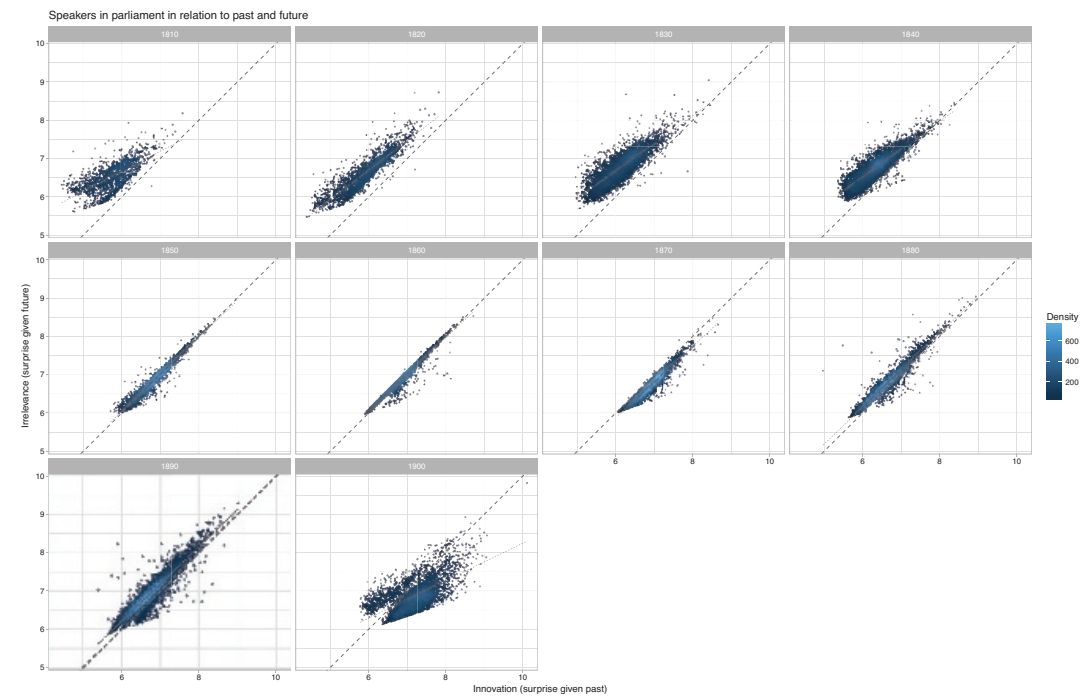

Figure 4. Relationship to past and future in speakers' lexicons in Hansard, I810-1900, broken up by decade. DeDeo plot measuring innovation (distance from past) against irrelevance (distance from future), as calculated by Kumar-Johnson distance to the lexicons of speakers ten years before and after the year of each speech. 
The decades individually demonstrate a gradual 'drift' towards innovation, away from the replication of the language of the past, in each decade until I 870 (see Fig. 4). To judge the movement of lexicon by decade, the top 5000 speakers who gave the highest number of speeches were used as data for a novelty versus transience plot. The evidence shows a marked trend towards innovation from I 840 to I 870 . Speakers in each decade until I 870, it seems, were conscientiously trying to create a new language of Reform, of Liberalism, or of Conservativism, a movement that historians would traditionally associate with middleclass and popular movements for reform, party formation, Disraeli's Tamworth Manifesto on Conservative party identity, and the circulation of debates in newspapers. ${ }^{38}$

Indeed, the growth of newspaper circulation after the expansion of the franchise in I867, as described by Ryan Vieira, would suggest that MPs might have been incentivized to further distinguish themselves, through new language and party positions, for their increasingly attentive constituents. ${ }^{39}$ In fact, the opposite seems to have been true. After I 870, perhaps through the pressure to manufacture more speeches on a regular basis, there was a retarding effect on the language of parliament; words spoken in I880 and I890 were overall closer to those of

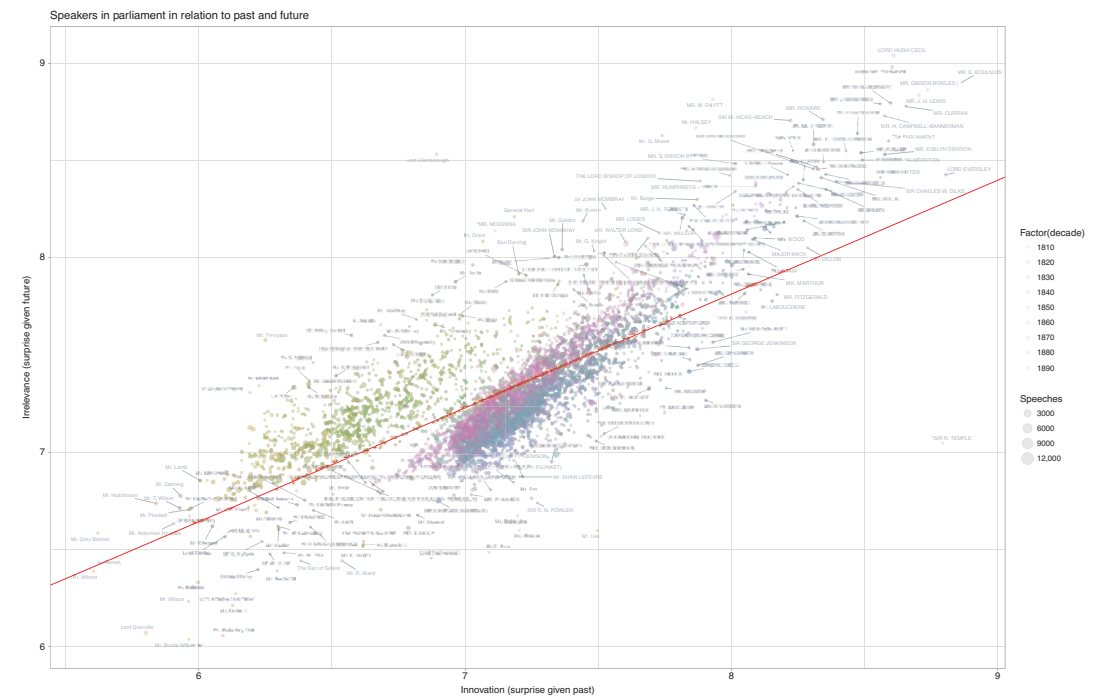

Figure 5. Speakers' lexicons of top 5000 speakers in Hansard, I8IO-I900, with decades highlighted. 
I 870 and I880 than had been the lexicon of I850 or I860 when compared to I 840 or I 850 .

At the level of decades, the drift away from aristocratic institutions and towards democracy is less visible as of I809, for instance, when 'lord' and 'nobl-' were on the rise, discussions of Irish Catholics and the constitution on the wane, put to flight by a tide of anti-Bonapartism (see Fig. 5).

Abstractions of decade-long changes reveal patterns of change that suggest very different images of the future as imagined within any decade-long slice of time. In I 840 (not shown), discussions of anti-slavery and sugar were mounting; in I 870 (also not shown), anti-landlord politics and the discussion of Irish tenants, and discussions of education and government boards were on the wane, while in I 880 (Fig. 7), Ireland was on the decline. In I880, new Conservative government was interested in police and India but not in Ireland, tenants and the price of rent, suggesting that the political concept of 'rent' was closely linked to the temporality of Ireland. The divergence measures also highlight the rise of 'courtesy' language marked by the use of formal titles such as 'honourable', 'sir' and 'gentleman' to invoke other speakers (see Fig. 6 and Fig. 7).

The aggregation of trends goes to prove something quite obvious to most political historians: that from the vantage of any given year, the fate of the future hangs upon which party is in power, and the future mapped out by Gladstone's government was quite different from the Robert Gascoyne's. On the other hand, however, aggregate comparisons of language have never before available to the professional historian on such a scale. Glancing over them allows the scholar to define the long-term stakes of short-term victories. For instance the Conservative idiom of gentility mapped out by the language of 'honourable gentlemen', might have been trending in I 889 , but would not be remembered in I890. Conservatives of the I880s were more influential, however, in the reach of the institutional forms that they insisted on: a greater role for governance of the colonies through secretaries, the oversight of boards for domestic government, the importance of the treasury. As terms, these institutional pieces would be statistically ascendant over the whole second half of the century (from I 852-I9I I).

Indeed, it is the possibility of abstract aggregation that promises to be instructive to the historian who wishes to synthesize trends and moments of political reorientation in modern textual corpora. Moments 
GULDI

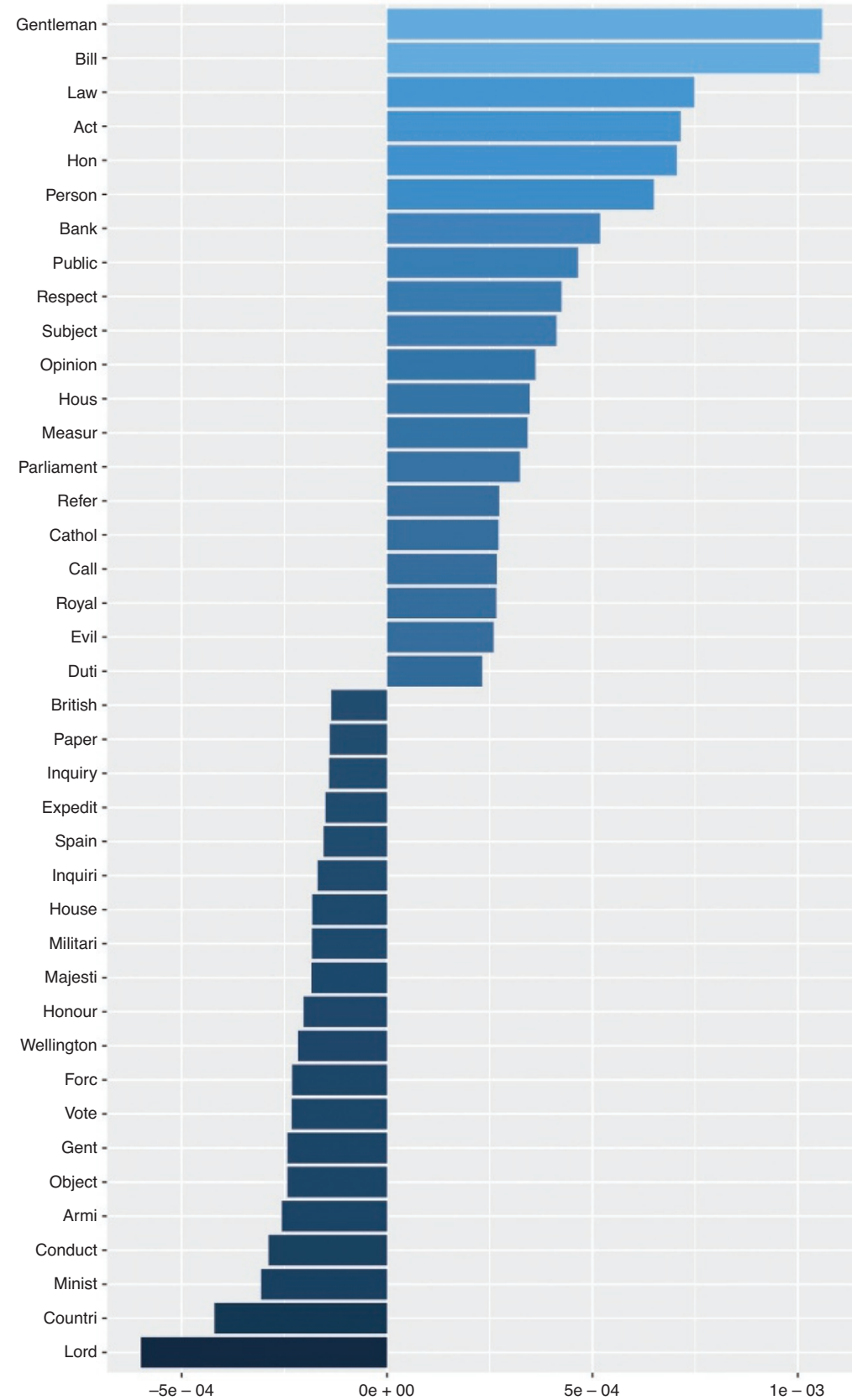

Figure 6. Words favoured by innovative speakers, I8IO-I8I9, and words favoured by irrelevant speakers, according to a partial Jenson-Shannon distance of speakers classed as 'more innovative' or 'more irrelevant' in Figure 4. 


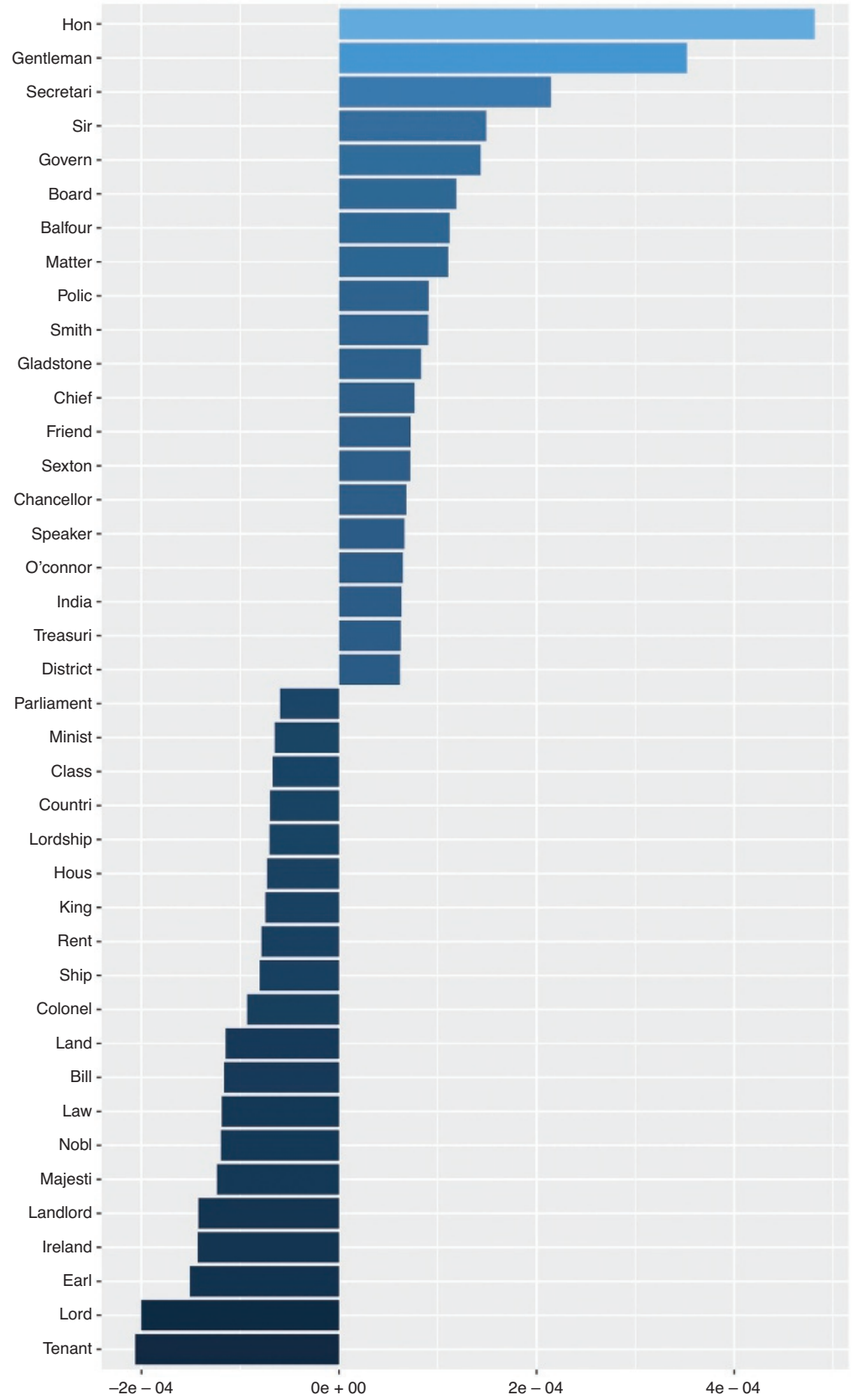

Figure 7. Words favoured by innovative speakers, I880-1889, and words favoured by irrelevant speakers, according to a partial Jenson-Shannon distance of speakers classed as 'more innovative' or 'more irrelevant' in Figure 4. 
of political identity-making that have come down through the historiography (for instance the Tamworth Manifesto) may be checked against quantitative influence of the imprint they left on the political lexicon of those they influenced. The measures deal in large and general comparisons: demonstrating, for instance, the difference between leaders such as Gladstone and Disraeli, whose lexicons are as central as possible to the distribution of other speakers' relationships to modernity, and A. J. Balfour in the I 880 os and Richard Temple, who were at the time actively and persistently advancing a new language that would be taken up after their own time (see Figs. 3, 7) ${ }^{40}$

Despite the strong language in which these findings have been presented, the results of this section in particular must be regarded as preliminary, as further cleaning of speaker data will be necessary for a more careful reading of individuals. Thus the above results are presented not as a final testimony of the dynamics of the I880s, but as a dress rehearsal that allows the scholar to critique the most useful possibilities as well as some possible weaknesses of the method itself. ${ }^{41}$

\section{Potential Weaknesses of Information Measures}

Because divergence measures are new to practicing historians, we are still working on gaining familiarity with how small choices (for instance, the choice of measuring divergence of speaker lexicon versus divergence of speaker topic) impact the findings that result.

These questions raise larger issues with the method, which are open to further experimentation: is it really legitimate to measure all topics, or all words in the lexicon, as indices of the change of ideas? From topic modelling Hansard, we know that fully half of the text base is composed of 'performative' language wherein speakers describe the dynamics of asking a question, objecting to someone else's statement or inviting the attention of other speakers to a related matter. ${ }^{42}$ Measuring dynamics of influence around performative language may certainly tell scholars something about the parliamentary leaders who set the trend for how speakers interacted, but measuring performative influence is not the same as measuring who the most influential leader was in terms of ideas. There are solutions, in this case: some scholars of topics have suggested the usefulness of stop-wording out everything besides nouns, 
with the result of producing a topic or lexicon of ideas, material landscapes and other themes of debate. ${ }^{43}$ A scholar working on influence might use the topic of 'performative language', as well as non-noun language, as a starting point for specifying a lexicon of 'political subject matter'. Such a specific lexicon as this might offer an alternative basis for measuring innovation and irrelevance.

Another possible weakness of an approach that highlights individuals is treating individual lexicons as static, when individual speakers adjusted their lexicons over time. In the project at stake, speaker lexicons have been measured within each calendar year for how different that lexicon was from everything spoken afterwards on a ten-year horizon. Arbitrary cut-off dates of this kind introduce some bias, which would need to be adequately measured and compared to samples conducted on the scale of months or days in order for a scholar to come to a more informed opinion of what dynamics of change and influence look like on different scales. Looking at finer and grosser scales would allow a scholar to ask questions about how Gladstone changed his idiom over a particular question or around a particular event. ${ }^{44}$ More serious concerns, however, relate to extrapolating easy conclusions about the most innovative speakers on the basis of raw divergence counts.

The measure of divergence raise particular questions about political trends that beg for further work with the data. Among the speakers studied in this project, the ones with the most radical lexicon were also, frequently, the ones who changed relatively little over the course of the decade, insisting instead on the importance of peasants, the tenantry and the revision of rent, even when the rest of parliament had adopted the language of empire. Isaac Butt, for example, leader of the Irish opposition, is ranked by the measure as highly irrelevant and only moderately innovative. Radicals who insist on alluding to peasant troubles with rent in every speech for a decade are not ranked as 'innovative' here, insofar as they carry the baton of an earlier generation speaking of the same trouble. If their language is not carried forward, they will be dismissed as 'irrelevant'. Meanwhile, Arthur Balfour, scourge of the Irish tenant, is shown by these measures to have been among the most innovative speakers of the century, as well as influential, in all of his speeches (Fig. 3). According to the measure, Conservatives thus appear as more 'modern' than radicals, a finding that begs for interpretation and inspection. 
Balfour and other Conservatives of the I880s were working to advance a new set of idioms, concepts and parliamentary objects to reorient politics from the Liberal and Irish causes of the I870s. Future iterations through the data require a researcher to ask more questions about how and why Conservative language appeared so distinct in the I880s: was it mainly in terms of a new set of temporal concerns, for example a shift away from Ireland to Egypt and the Transvaal? What intellectual concepts marked the novelty of Conservative speakers? If re-measured with a controlled vocabulary of abstract concepts instead of a lexicon in general, would the same conclusions still hold? In this way, measures of innovation beget new questions that can be iteratively addressed with measures of divergence.

Similar problems can be identified with the aggregate measurement of lexicon change over an arbitrary period of time. The cut-off measurement of change to I 890 poses a problem; Butt might appear more relevant than Balfour if the cut-off date were I886. This problem of 'arbitrary baselines' is an issue, insofar it prejudices the causal inferences found by quantitative measures in most of the work on influence that has been published using similar methods to date, including a study of music that identified the Beatles as the most influential music group of the post-war era. ${ }^{45}$

If I 890 or some other date is used to establish a baseline measure of historical change over time, then scholars must be explicit about the fact that they are measuring the relative liability of discourses to converge at a particular point of time, which is not the same, of course, as the Zeitgeist although it may reflect a partial dialectic or even a process of conservative backlash like those identified by Adorno as a 'negative dialectic'. Baseline measures therefore may be useful for establishing raw 'influence', or for comparing degrees of change. But in essence, these data return us to another question - what is meant by 'modernity' - which has a rich literature in conceptual history and the analytics of periodization behind it.

Thus the problem of measuring 'modernity', even when pursued through data, brings scholarship face-to-face with interpretive issues. By the measure of the I880s, the most forward-looking speakers in parliament, by the measures we have established, were those advancing an imperial agenda associated with the Conservative party, thus debating Turkey, Egypt and the Transvaal: they were the most novel in that 
they were proposing a wider sweep of empire than ever before, using jingoistic and patriotic terms in new ways. The same voices would look hopelessly outmoded to Marxist and subaltern critics of their own time, as well as to their descendants in the I930s or I950s. In other words, we are easily led astray if the measures of modernity described here are taken as a metric of 'progress' or 'truth', rather than simply of local victory. Novelty, or innovation, as defined by the measure of closeness to later texts, is a local, not a universal, measure of influence over a measurable period of time, in this case a decade. On the moyenne durée of a decade, keyword-based metrics of linguistic innovation and its acceptance by others are not a proxy for identifying the arc of radicalism or justice. If Martin Luther King's paraphrase of Hegel is true ('the arc of history tilts towards justice'), then scholars may need to measure influence over even greater time scales, for instance centuries, in order to apply such metrics towards anything like a moral convergence.

The failure of metrics to identify a progressive convergence appears to be an issue not only of periodization, but also of dissent. The measure of modernity, as we have called the innovation and irrelevance metrics, is designed to capture growing influence, rather than to dramatize polarized views. Meanwhile, the mapping of the most influential strain in politics at any given time obviously masks all sorts of politics that mattered for history, both in terms of social experience beyond parliament and in terms of policies beyond the ten-year window tested in this article's examples. Political or moral consensus, progress and divergence resist the measure of modernity for another set of reasons: the permanence and unchanging status of the subaltern citizen during much of the modern period.

The foregoing investigation of divergence measures highlights enormous advantages relating to the abstraction of change over time, in distinction to the foregoing naive count of words or phrases or the indexing of time with topic models. As the examples here demonstrate, however, care is also required in the interpretation of markers of progress as defined by these quantitative metrics, in terms of recognizing linguistic versus conceptual change, treating baseline cut-off dates as arbitrary, and the interpolating 'progress' from markers that can be arbitrary as well as indicative. With these cautions in hand, the measures may nonetheless be useful.

The changing content of modern speech can be identified via statistical measures that highlight the distinctive attributes of two overlapping 


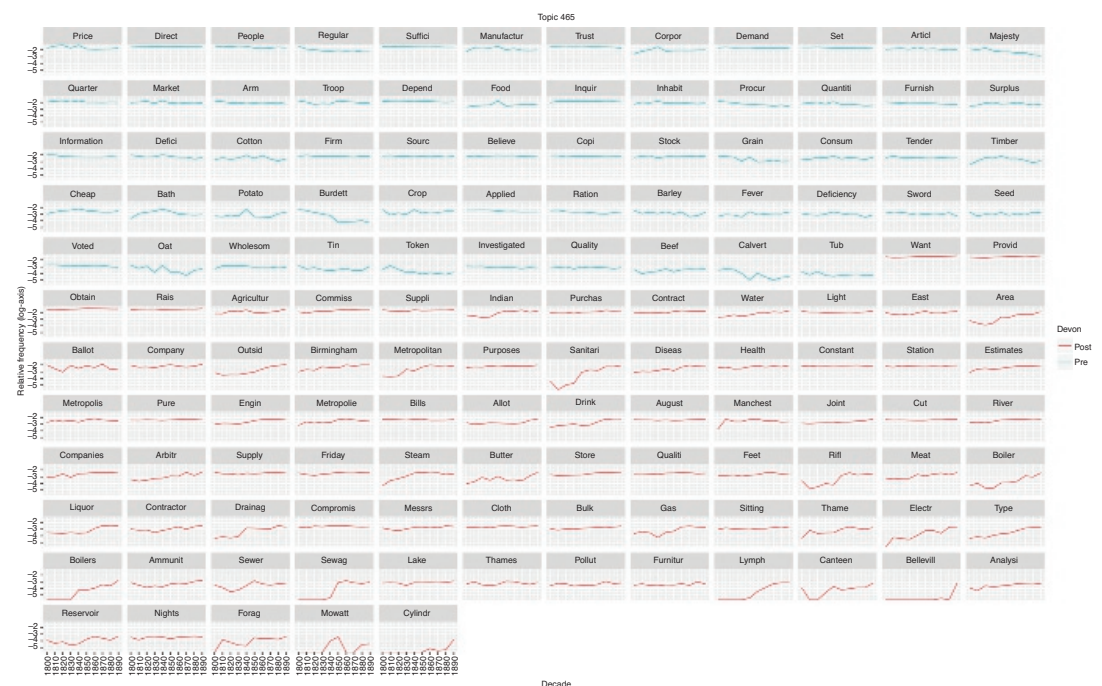

Figure 8. Topic 150, 'The Supply of Water, Food, and Meat', via a dynamic topic model $(k=500)$ of Hansard's parliamentary debates, I803-I9II.

groups of data. Hybrid approaches are more useful for pinpointing the coincidence between rhetorical change and changing political objects. ${ }^{46}$ For instance, topic models have been used in conjunction with divergence measures to index change. ${ }^{47}$ Divergence measurement of keyword frequency in the State of the Union speeches in the United States, for example, defined four moments of discontinuity. ${ }^{48}$

Iterating over the work presented here with hybrid forms of knowledge can push conclusions to become more exact. For instance, in Fig. 9, a hybrid visualization amplifies the information from dynamic topic model from Figure I by adding the stories of individual word counts over time, separated by those that have a peak before I 845 (above) and those after (below) arranged in order of maximum from beginning of the century to end. The visualization makes it relatively easy to compare the words with the strongest tendency towards decline ('oat', 'barley', 'sword', and 'timber') with those on the rise ('outsid*', 'sanitari*', 'steam', 'butter', 'meat', 'electr*', 'sewag*', and 'lymph'), thus gleaning a more precise understanding of the dynamics within the 'Supply of Water, Food, and Meat' topic. The visualization also allows, at a glance, insight into the relative continuity of expression over time 


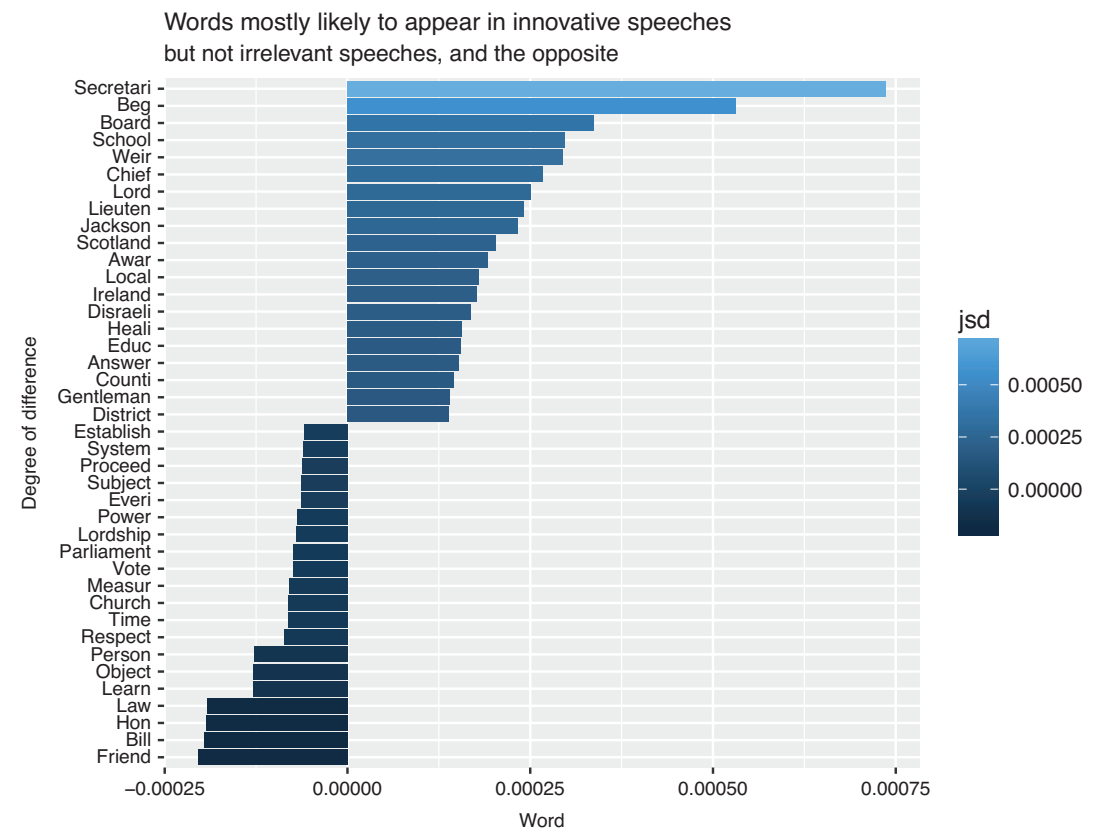

Figure 9. Words most likely to occur in speeches by 'innovative' speakers but not 'irrelevant' speakers and the opposite.

over the majority of terms in this particular topic - a feature that would appear different from topic to topic.

Similarly, combining divergence measures of speaker performance with divergence measures of words most likely to be used by particular speakers can result in a richer harvest of insight about what 'innovative' speech means in the context of parliament.

Overall, what emerges most clearly from these findings is the language of parliamentary courtesy in each debate. The innovative were liable to invoke a language of Christian charity, both 'begging' the listeners for their attention and summoning the 'healing' of the body politic. The speakers classed as 'irrelevant' to the future, according to the algorithm, seem to have favoured a lexicon of high courtesy (see Fig. 9). Above all, they were punctiliously polite to their fellow representatives, referring to another member as 'my honourable friend'. They also liked to suggest the importance of subordination, to 'lordship', to 'power', to the 'system', invoking 'votes' and 'proceedings' and the worth of 'time', and alluding to other 'principles' of the parliamentary process. 
In short, they were speakers in the thrall of a passing system. Whether this relationship between passing concern is an artefact of party structure (where more influential speakers used less courtesy), or a shift in the conventions of speech (where linguistic formulae for courtesy changed) is the subject of further research.

Hybrid forms of word count, divergence, and topic modelling form a growing presence everywhere in the digital literature. As the above exercises show, they dominate precisely because hybrid approaches critically build on the shortcomings of any one approach.

\section{Conclusion}

Particular approaches to textual knowledge lend themselves more or less to the theoretical problems of 'objective' and 'subjective' modernity, as this article has demonstrated. 'Objective' changes in modernity such as changes to the built environment are easily apprehended by use of a topic model of a large body of text, while 'subjective' changes to modernity are more easily picked up on at the level of the phrase.

Comparison of different approaches also suggests the 'fit' of information theory to understanding more accurately the question of change over time in particular. Against keyword and phrase measures and topic modelling, which provide indices, respectively of how and what was talked about, information theory stands out as a particularly useful tool for the historian. With keyword search and topic modelling, we have tools for matching documents and themes. Only with information theory, by contrast, do we apprehend a tool for abstracting change itself. It is, in short, because of the possibility of abstracting the difference between any two dates within any one corpus that information theory promises to help the synthesizing historian to characterize large swaths of time. If land had been made an issue for parliament in the I870s, then colonial secretaries and government boards were made an issue in the I880s. The measure of irrelevance and innovation thus allows a scholar to paint with a broad brush, characterizing the contributions of any given event or decade to the 'modern' language of British politics that was ascendant for the period I852-I9I I.

Measures of modernity such as innovation and irrelevance give us new insight into the permanent realities that defined Britain. They 
validate the centrality of public education and schools to the changing political index. Hybrid measures, in particular, allow the scholar to make arguments about change over time with remarkable specificity as to speaker, party, subject and year of change.

Finally, this article suggests that scholars of modernity will be served by an enterprise that weds theory and mathematics in the question of when and how change came to different indices of modernity, both the subjective and the objective. To highlight the need for theory and the failure of the data to foreclose the definition of modernity is not to invalidate the power of the foregoing measurements, nor the applicability of data to questions of historical change. Keyword-based measures of innovation do still illuminate some of the dynamics by which policy was made: empire, education and environment were ineluctable as subjects of government in the modern period, and those who kept those subjects in their sites were liable to cut a trend in policy that would be copied by others. Considering the centrality of theories of modernity and the multiple possible definitions of modernity rather points us to a new frontier of digital research, where future researchers might plausibly consider how data-driven tests might be used to illuminate theories of multiple periodization. Even more specifically, theories of agency might be used to identify the evidence of multiple kinds of influence at work in the archive.

The frontier of data-driven research is a frontier that will be satisfied not by more mathematics alone, but by a search for the best algorithms to 'fit' questions about agency, influence, change and modernity that have been raised outside of the world of data. It is a domain in which the students of conceptual history, social theory and critical thinking about periods, individuals and linguistic conventions all have a place, arguing and tinkering alongside the scholars of algorithms and statistics.

\section{Notes}

I Jo Guldi, 'Critical Search: A Procedure for Guided Reading in Large-Scale Textual Corpora', Journal of Cultural Analytics (2018), I-35 (https://doi. org/I0.22 I48/I6.030).

2 Gavin Murray-Miller, 'Civilization, Modernity and Europe: The Making and Unmaking of a Conceptual Unity', History I03:356 (2018), 4I 8-33 (https://doi.org/IO.I I I I/I468-229X.I26I4). 
3 Max Weber, Economy and Society (Berkeley, 20I3 [1922]); Lewis Mumford, Technics and Civilization (New York, I934); Quentin Skinner, The Foundations of Modern Political Thought (Cambridge, I978); Benedict Anderson, Imagined Communities: Reflections on the Origin and Spread of Nationalism (London, I983); Immanuel Wallerstein, The Politics of the World Economy: The States, the Movements and the Civilisations (Cambridge, I984); Uday Singh Mehta, Liberalism and Empire: A Study in Nineteenth-Century British Liberal Thought (Chicago, I999).

4 For instance, Emma Griffin, A Short History of the British Industrial Revolution (Houndmills, 20Io); Peter N Stearns, The Industrial Revolution in World History (London, 20I8) (https://www.taylorfrancis.com/ books/9780429494475).

5 Mary Poovey, 'Stories We Tell about Liberal Markets: The Efficient Market Hypothesis and Great-Men Narratives of Change', Simon Gunn and James Vernon (eds), The Peculiarities of Liberal Modernity in Imperial Britain (Berkeley, 20I I), I99-2 I ; Gavin Rand, 'Same Difference? Liberalism, Modernity, and Governance in the Indian Empire', Gunn and Vernon (eds), Peculiarities of Liberal Modernity, I34-46; David Vincent, 'Government and the Management of Information, I 844-2009', Gunn and Vernon (eds), Peculiarities of Liberal Modernity, I65-8I.

6 Frederick W. Gibbs and Daniel J. Cohen, 'A Conversation with Data: Prospecting Victorian Words and Ideas', Victorian Studies 54, no. I (20 I I), 69-77.

7 Bob Nicholson, 'Counting Culture; or, How to Read Victorian Newspapers from a Distance', Journal of Victorian Culture I7:2 (2012), 238-46 (https:// doi.org/IO.I080/I3555502.20I2.68333I).

8 Thomas Lansdall-Welfare, Saatviga Sudhahar, Justin Lewis ,James Thompson and Nello Cristianini, 'Content Analysis of I 50 Years of British Periodicals, PNAS (Proceedings of the National Academy of the Sciences) I I4:4 (2017), E457-E465 (https://doi.org/Io. I073/pnas. I606380 I I4).

9 One statistical, quantitative and frequently geospatial approach appears in Dan Bogart's work on the impact of railways on local economies, esp. Dan Bogart, 'Clio on Speed', in Handbook of Cliometrics, Claude Diebolt and Michael Haupert (eds) (Berlin, 20I9), I453-78 (https://doi. org/I0.I007/978-3-030-00I8I-0_67).

Io Three examples of discursive and literary analysis by quantitative means for modern Britain are: Marc Alexander, 'The Metaphorical Understanding of Power and Authority,' Mapping English Metaphor Through Time 
Wendy Anderson, Ellen Bramwell and Carole Hough (eds) (Oxford, 2016), I9I-207; Matthew L. Jockers and David Mimno, 'Significant Themes in I9th-Century Literature', Poetics 4I:6 (2013): 750-69; and Luke Blaxill, 'Quantifying the Language of British Politics, I880-I9Io', Historical Research 86:232 (20I3), 3I3-4I (https://doi.org/Io.I I I I/I468228I.I20II).

I I Lansdall-Welfare et al., 'Content Analysis of I50 Years of British Periodicals'.

I 2 Consider the title of Sara Klingenstein, Tim Hitchcock and Simon DeDeo, 'The Civilizing Process in London's Old Bailey', Proceedings of the National Academy of Sciences III:26 (2014), 94I9-24 (https://doi. org/Io. I073/pnas. I 405984 I I I ).

I3 Lansdall-Welfare et al., 'Content Analysis of I50 Years of British Periodicals'; Klingenstein et al, 'The Civilizing Process in London's Old Bailey'; Ryan Cordell, 'Reprinting, Circulation, and the Network Author in Antebellum Newspapers', American Literary History 27:3 (2015): 4I7-45 (https://doi.org/Io.I093/alh/ajvo28); Katherine Bode, 'Fictional Systems: Mass-Digitization, Network Analysis, and Nineteenth-Century Australian Newspapers', Victorian Periodicals Review 50:I (2017), I0038; Eve Kraicer and Andrew Piper, 'Social Characters: The Hierarchy of Gender in Contemporary English-Language Fiction', Journal of Cultural Analytics (2019) (https://doi.org/I0.22I48/I6.032); Andrew Goldstone and Ted Underwood, 'What Can Topic Models of PMLA Teach Us About the History of Literary Scholarship', Journal of Digital Humanities 2:I (20I2) 40-9; Ted Underwood, 'Theorizing Research Practices We Forgot to Theorize Twenty Years Ago,' Representations I27:I (2014), 64-72 (https://doi.org/I0.I525/rep.20I4.I 27.I.64); Ted Underwood, 'A Genealogy of Distant Reading', Digital Humanities Quarterly I I:2 (2017); Ted Underwood, David Bamman and Sabrina Lee, 'The Transformation of Gender in English-Language Fiction', Journal of Cultural Analytics (20 I 8) I-32 (https://www.ideals.illinois.edu/handle/2 I42/990 I5).

I4 Andrew C. Eggers and Arthur Spirling, 'The Shadow Cabinet in Westminster Systems: Modeling Opposition Agenda Setting in the House of Commons, I832-I9I5,' British Journal of Political Science 48:2 (2016), I-25; Jo Guldi, 'Parliament's Debates about Infrastructure: An Exercise in Using Dynamic Topic Models to Synthesize Historical Change,' Technology and Culture 60: I (2019), I-33. 
I5 James A. Evans and Pedro Aceves, 'Machine Translation: Mining Text for Social Theory', Annual Review of Sociology 42: I (20I6), 2I-50 (https://doi.org/Io. I I46/annurev-soc-08I7 I5-074206); Achim Edelmann and John W. Mohr, 'Formal Studies of Culture: Issues, Challenges, and Current Trends,' Poetics 69 (2018): I-9 (https://doi.org/Io.IoI6/j. poetic.20I 8.05.003); Richard Jean So, “"All Models Are Wrong”,' PMLA I32:3 (20I7), 668-73 (https://doi.org/Io.I632/pmla.20I7.I32.3.668); Ken Benoit, 'Quantitative Analysis of Textual Data for Social Sciences', Impact 4 (20 I 8), 22-4; Jonathan B. Slapin et al., 'Ideology, Grandstanding, and Strategic Party Disloyalty in the British Parliament', American Political Science Review I 2: I (2018), I5-30; Jelle W. Boumans and Damian Trilling, 'Taking Stock of the Toolkit: An Overview of Relevant Automated Content Analysis Approaches and Techniques for Digital Journalism Scholars', Digital Journalism 4: I (2016), 8-23; Naoki Egami et al., 'How to Make Causal Inferences Using Texts', ArXiv Preprint ArXiv:I802.02I63 (20I8) (https://scholar.princeton.edu/sites/default/ files/bstewart/files/ais.pdf); Justin Grimmer, 'We Are All Social Scientists Now: How Big Data, Machine Learning, and Causal Inference Work Together', PS: Political Science \& Politics 48: I (2015), 80-3; Justin Grimmer and Brandon M. Stewart, 'Text as Data: The Promise and Pitfalls of Automatic Content Analysis Methods for Political Texts', Political Analysis 2 I:3 (2013), 267-97; Margaret E. Roberts, Brandon M. Stewart, and Edoardo M. Airoldi, 'A Model of Text for Experimentation in the Social Sciences', Journal of the American Statistical Association I I I:5 I 5 (2016), 988-I003; Margaret E. Roberts et al., 'Structural Topic Models for Open-Ended Survey Responses', American Journal of Political Science 58:4 (2014), I064-82.

I6 The plausibility of the debates as a historical source for understanding cultural change, as well as the nature of the data, has been discussed in Guldi, 'Parliament's Debates about Infrastructure'.

I7 Andrew C. Eggers and Arthur Spirling, op. cit.

I 8 John Sinclair, History of the Origin and Progress of The Statistical Account of Scotland (Edinburgh, I798); Henry Parnell, A History of the Penal Laws Against the Irish Catholics (London, I825); William Cobbett, A History of the Protestant Reformation in England and Ireland: Showing How That Event Has Impoverished the Main Body of the People in Those Countries (London, I829); Benjamin Disraeli, Coningsby: The New Generation (London, I844); Thomas Babington Macaulay, The History of England 
from the Accession of James II (Boston, I849); Thomas Baines and Edward Baines, Yorkshire, Past and Present: A History and a Description of the Three Ridings of the Great County of York, from the Earliest Ages to the Year I870 (London, I87I, 2 vols.); William Forsyth, The Rules of Evidence as Applicable to the Credibility of History (London, I874); Henry Richard, History of the Origin of the War with Russia (London, I876); William E. Gladstone, The Royal Supremacy; as It Is Defined by Reason, History and the Constitution (London, I877); Justin McCarthy, A History of Our Own Times. a New Edition. (London, I882); James E. Thorold Rogers, Six Centuries of Work and Wages. the History of English Labour, (New York, I884); Justin McCarthy, A History of the Four Georges (London, I884); Justin Huntly McCarthy, Ireland Since the Union: Sketches of Irish History from I 798 to I886 (Chicago, I889); Herbert Butterfield, The Whig Interpretation of History (New York, I965).

I9 Asa Briggs, The Age of Improvement, I783-I867 (New York, I962), Christopher Otter, The Victorian Eye: A Political History of Light and Vision in Britain, I8OO-I9IO (Chicago, 2008).

20 Poovey, 'Stories We Tell about Liberal Markets'.

2 I George W Stocking, Observers Observed: Essays on Ethnographic Fieldwork (Madison, I985), e.g. 88-90.

22 Charles Adderly, 'Steam Communications with India \&c.', Hansard House of Commons (March 27, I85I), col 657.

23 Humanistic practices with topic models have been explored in a variety of journal articles: Allen B. Riddell, 'How to Read 22, I98 Journal Articles: Studying the History of German Studies with Topic Models', Matt Erwin and Lynne Tatcock (eds), Distant Readings: Topologies of German Culture in the Long Nineteenth Century (New York, 20I4), 9I-I I4; Lauren Klein and Jacob Eisenstein, 'Reading Thomas Jefferson with TopicViz: Towards a Thematic Method for Exploring Large Cultural Archives', Scholarly and Research Communication 4:3 (20I3), I-I2 (http://www.src-online. ca/index.php/src/article/view/I2I); Glenn Roe, Clovis Gladstone and Robert Morrissey, 'Discourses and Disciplines in the Enlightenment: Topic Modeling the French Encyclopédie', Frontiers in Digital Humanities 2 (2016), 335-7 (https://doi.org/I0.3389/fdigh.2015.00008); Cameron Blevins, 'Space, Nation, and the Triumph of Region: A View of the World from Houston', Journal of American History IO I: I (20 I4), I 22-47 (https:// doi.org/I0.I093/jahist/jauI84); David J. Newman and Sharon Block, 'Probabilistic Topic Decomposition of an Eighteenth-Century American 
Newspaper', Journal of the American Society for Information Science and Technology 57:6 (2006), 753-67 (https://doi.org/Io. I002/asi.20342).

24 Roe, Gladstone and Morrissey, 'Discourses and Disciplines in the Enlightenment'.

25 Guldi, 'Parliament's Debates about Infrastructure'; Jo Guldi and Benjamin Williams, 'Synthesis and Large-Scale Textual Corpora: A Nested Topic Model of Britain's Debates over Landed Property in the Nineteenth Century', Current Research in Digital History I (2018) (https://doi. org/I0.3 I835/crdh.20 I8.0I).

26 David M. Blei, Andrew Y. Ng and Michael I. Jordan, 'Latent Dirichlet Allocation', Journal of Machine Learning Research 3:4/5 (2003), 993I022; John W. Mohr and Petko Bogdanov, 'Introduction - Topic Models: What They Are and Why They Matter,' Poetics 4I:6 (2013), 545-69.

27 David Blei and John Lafferty, 'Dynamic Topic Models', Proceedings of the 23rd International Conference on Machine Learning (2006), I I3-20.

28 For NMF in parliamentary history in general, see Derek Greene and James P. Cross, 'Exploring the Political Agenda of the European Parliament Using a Dynamic Topic Modeling Approach,' ArXiv:I607.03055 [Cs] (20I6) (http://arxiv.org/abs/I607.03055). For Hansard as a source (and its limitations), see Sandra Mollin, 'The Hansard Hazard: Gauging the Accuracy of British Parliamentary Transcripts', Corpora 2, no. 2 (2007): I 87-2 Io (https://doi.org/I0.3366/cor.2007.2.2.I87).

29 Guldi, 'Parliament's Debates about Infrastructure'. Readers may explore our (static) topic model on their own here: https://eighti9i I.github.io/ hansard/home/. There are some discrepancies from the dynamic topics described in this article. In order to prepare the corpus for analysis, the words of Hansard's parliamentary debates were lemmatized, and the topic model was instructed to find the twenty words most statistically significant for 500 topics in Hansard. Following a convention now typical among digital researchers, scholars then used the computer-generated keywords to assign names to the dynamic topics. For 'Turnpike Trust' (Topic 326), the overall top words are: 'trust', 'truste*', 'turnpik*', 'abl*', 'chariti*', 'trusts', 'road*', 'whatev*', 'trustees', 'persever*', 'serious', 'acced*', 'sincer*', 'confid*', 'satisfactori*', 'secur*', 'assur*', 'control.' For 'Railways' (Topic I I4), the words are: 'railway', 'railways', 'companies', 'construct', 'western', 'traffic', 'train*', 'accid*', 'passing*', 'station*', 'road*', 'mile*', 'travel*', 'carriag*', 'railroad*', 'canal*', 'mail*', 'director*', 'accidents', 'north.' For 'Post Office, Transport, and Telegraph' (Topic 
284), the words are: 'post', 'telegraph*', postmast*', 'mail*', 'stamp*', 'postal', 'parcel*', 'postmaster*', 'hanbury', 'postag*', 'telephon*', 'letter', 'deliveri*', 'newspap*', 'palmer', 'messag*', 'packet*', 'Patrick', 'wire*', 'convey.'

30 For 'Architect Plans for Parks and Development' (Topic 250), the overall top words are: 'plan*', 'Ayrton', 'best', 'park*', 'owen', 'adopted', 'submit*', 'architect', 'annuiti*', 'plans', 'metropolitan', 'proposed', 'works', 'devis*', 'barri*', 'design*', 'project*', 'accord*', 'detail*', 'hill*.' For 'London's Infrastructure' (Topic 420), the words are: 'London', 'citi*', 'metropolis', ‘metropolit*', ‘city', 'metropolitan', ‘club', ‘middlesex', 'York', 'port', 'street', 'merchant', 'banburi*', 'aldermen', 'Westminster', 'market', 'spot', 'similar', 'western', 'attendance.'

3I For 'Eminent Domain', the words are: 'applic*', 'refus*', 'explained', 'dispos*', 'special', 'capit*', 'application', 'received', 'evict*', 'refused', 'compli', 'reinstat*', 'certify*', 'applications', 'patent', 'sanction', similar', 'granted', 'acced*', and 'behalf.'

32 For details of the topic models, see Guldi, 'Parliament's Debates about Infrastructure'.

33 Chris Otter, 'The British Nutrition Transition and Its Histories', History Compass I0: I I (20I2), 8 I 2-25 (https://doi.org/IO. I I I /hic3.I 200I).

34 Simon DeDeo et al., 'Bootstrap Methods for the Empirical Study of Decision-Making and Information Flows in Social Systems', Entropy I 5:6 (20I3), 2246-76 (https://doi.org/I0.3390/e I5062246); Sara Klingenstein, Tim Hitchcock and Simon DeDeo, 'The Civilizing Process in London's Old Bailey', Proceedings of the National Academy of Sciences I I I:26 (20I4), 94I9-24 (https://doi.org/I0.I073/pnas. I405984 I I I).

35 Peter De Bolla, The Architecture of Concepts: The Historical Formation of Human Rights (New York, 20I3); Matthew Lee Jockers, Macroanalysis: Digital Methods and Literary History (Urbana, 20I7); Dan Edelstein, 'Intellectual History and Digital Humanities', Modern Intellectual History I3: I (20I6), 237-46.

36 Alexander T. J. Barron et al., 'Individuals, Institutions, and Innovation in the Debates of the French Revolution', Proceedings of the National Academy of Sciences II5:I8 (2018), 4607-I2 (https://doi.org/Io.Io73/ pnas.I7I7729I I5).

37 Barron et al., Ibid.

38 Matthew Cole and Helen Deighan, Political Parties in Great Britain (Edinburgh, 20I2), 77-9. 
39 Ryan A. Vieira, Time and Politics: Parliament and the Culture of Modernity in Nineteenth-Century Britain and the British World (Oxford, 20 I5) (http:// search.ebscohost.com/login.aspx?direct=true $\&$ scope $=$ site $\& \mathrm{db}=$ nlebk $\& \mathrm{db}$ $=$ nlabk\&AN=I003234).

40 Interestingly, A. J. Balfour in later decades would join the centremost cluster of party leaders. Each speakers' data, in this exercise, is broken up by decade, such that there is more than one observation on the charts for Balfour, Parnell and others.

4I The author anticipates revisiting the question of speaker context change with a cleaner data set within the next year in an article specifically about that part of the data. For this reason, the author has opted not to share the preliminary clean data or code at this point, with the understanding that the main purpose of the current article is to critically review existing approaches rather than to posit final, objective results.

42 Guldi and Williams, 'Synthesis and Large-Scale Textual Corpora'.

43 Roe, Gladstone and Morrissey, 'Discourses and Disciplines in the Enlightenment'.

44 For a historical take on speaker lexicons in the age of Gladstone, which suggests that such an approach might be profitable, Luke Blaxill, 'Quantifying the Language of British Politics, I880-I9I0', Historical Research 86:232 (20I3), 3 I3-4 I (https://doi.org/IO. I I I I/I468-228 I. I 20 I I). For a statistical take on better ways to identify speakers' unique lexicons, see Ben Blatt, Nabokov's Favorite Word Is Mauve And Other Experiments in Literature. (Riverside, 2017) (http://public.eblib.com/choice/PublicFullRecord. aspx? $=5696934)$. The author is currently working on applying these tools to study individual speaker lexicon over time.

45 Uri Shalit, Daphna Weinshall and Gal Chechik, 'Modeling Musical Influence with Topic Models', Proceedings of the 3oth International Conference on Machine Learning 28:2 (20I3):244-52 (http://www.jmlr. org/proceedings/papers/v28/shalit I 3.pdf).

46 Guldi and Williams, 'Synthesis and Large-Scale Textual Corpora'.

47 Barron et al., 'Individuals, Institutions, and Innovation'.

48 Jean-Philippe Cointet, Alix Rule and Peter S. Bearman, 'Lexical Shifts, Substantive Changes, and Continuity in State of the Union Discourse, I790-20I4', PNAS II2:35 (20I5) I0837-44 (https://doi.org/Io.Io73/ pnas. I 5 I222 I I I2). 


\section{About the Author}

Jo Guldi is Associate Professor of the History of Britain and its Empire at Southern Methodist University, a Fellow of the Center for Creative Computing there, and PI of an NSF grant entitled 'The Unaffordable World'. She is also the former holder of the Hans Rothfels chair at Brown University, a former fellow of the Harvard Society of Fellows, author of Roads to Power (Harvard, 20I2) and co-author, with David Armitage, of The History Manifesto (Cambridge, 20I4). E-mail: jguldi@mail.smu.edu 